\title{
Relationship between the findings of pure-toneaudiometry and otoacoustic emission tests on military police personnel
}

\section{Relação entre os achados da avaliação audiométrica e das emissões otoacústicas em policiais militares}

\author{
Heraldo Lorena Guida', Ariane Laís de Sousa², Ana Cláudia Vieira Cardoso³. \\ 1) Doctor. Assistant Professor - Level II. \\ 2) Professional Development in Speech. Speech. \\ 3) Doctor. Assistant Professor PhD - Level I. \\ Institution: Faculty of Sciences - Department of Speech Pathology, UNESP - Marilia. \\ Marilia/SP - Brazil. \\ Mailing address: Heraldo Lorena Guida - Avenue Hygino Muzzi Filho, 737 - PO Box 181 - Marilia / SP - Brazil - Zip Code: $17525-900$ - Telephone: (+55 14) \\ 3402-1324 - E-mail: hlguida@ marilia.unesp.br \\ Foundation for Research Support of São Paulo - FAPESP (Process No. 08/50720-1 and 08/10903-0). \\ Article received June $15^{\text {th }}, 2011$. Article approved in September $17^{\text {th }}, 2011$.
}

\section{SUMMARY}

Introduction: Otoacoustic emissions can be an alternative for cochlear evaluation in noise induced hearing loss (NIHL). Objective: To investigate the correlation between the findings of audiometry results and distortion product otoacoustic emissions (DPOAE) in the military police.

Method: from cross-sectional and retrospective study, 200 military police officers were submitted to audiological evaluation - pure tone audiometry and DPOAE.

Results: considering the provisions of Ordinance 19 of the Labour Department, the results were suggestive of induced hearing loss by high sound pressure levels in 58 individuals, distributed as follows: 28 (48.3\%) bilateral cases and 30 (51.7\%) unilateral cases, and 15 (25.85\%) in each ear. The correlation between the audiometric and DPOAE showed statistical significance in most of the frequencies tested in both ears, confirming that the greater the degree of hearing loss, the smaller the DPOAE amplitudes. In addition, there was observed significant difference between the DPOAEs amplitudes of normal subjects and listeners with hearing loss, confirming the lowering of responses in the group with hearing loss.

Conclusion: considering that the correlation between pure tone audiometry and DPOAE, we conclude that otoacoustic emissions can be a complementary tool for the detection and control of NIHL in military police.

Keywords: evaluation, audiometry, police, military personnel.

\section{RESUMO}

Introdução: As emissões otoacústicas podem ser uma alternativa para avaliação coclear na perda auditiva induzida por ruído (PAIR).

Objetivo: verificar a correlação entre os achados da audiometria tonal e os resultados das emissões otoacústicas produto de distorção (EOAPD) em policiais militares.

Método: a partir de estudo transversal e retrospectivo, 200 policiais militares foram submetidos à avaliação audiológica - audiometria tonal liminar e EOAPD.

Resultados: considerando o disposto na Portaria 19 do Ministério do Trabalho, os resultados foram sugestivos de perda auditiva induzida por níveis de pressão sonora elevados em 58 indivíduos, distribuídos da seguinte forma: 28 (48,3\%) casos bilaterais e 30 (51,7\%) casos unilaterais, sendo 15 (25,85\%) em cada orelha. A análise de correlação entre a audiometria e as EOAPD, demonstrou significância estatística na maior parte das frequências testadas, em ambas as orelhas, confirmando que quanto maior o grau de perda auditiva, menor a amplitude das EOAPD. Além disso, foi observada existência de diferença significativa das amplitudes das EOAPD entre indivíduos normo ouvintes e portadores de perda auditiva, confirmando o rebaixamento das respostas no grupo com perda da audição.

Conclusão: considerando que houve correlação entre a audiometria e o teste de EOAPD, concluímos que as emissões otoacústicas podem ser uma ferramenta complementar, para a detecção e controle de PAIR em policias militares.

Palavras-chave: avaliação, audiometria, polícia, militares. 


\section{INTRODUCTION}

Noise at a sound pressure level of over $85 \mathrm{~dB}$ is considered hazardous to health, especially in the case of periodic exposure and a prolonged daily exposure time. Activities that include such levels of noise are thus considered unhealthy, and it is necessary to develop responsible attitudes to eliminate or neutralize such health risks. Noise impact is characterized by variations in the sound pressure level or sound spectrum, which shows acoustic energy peaks lasting for less than one second and intervals that last for more than one second (1).

Military is one of the sectors where workers are subjected to high noise levels particularly in the case of training with firearms (2). According to the 2007 census on the Brazilian Ministry of Justice (3), the number of professionals that work in state organs of public security (police officers, civilian police, and military firefighters) is 599.973. Of this number, 68\% (407.981) corresponds to military police.

Noise-induced hearing loss (NIHL) is characterized by a change in hearing thresholds as sensorineural, symmetrical, irreversible, and progressive hearing loss. NIHL initially affects the human hearing sensitivity in the frequency range of 3-6 kHz, where the threshold for 8 $\mathrm{kHz}$ must be better than the worst threshold (3, 4, or 6 $\mathrm{kHz}$ ) (4). The results of some studies on NIHL slightly differed classic literature on NIHL, whereas were found asymmetric hearing loss and/or unilateral configurations $(5,6)$. The authors of these studies attributed this divergence to the influence of the location of the sound source $(5,6,7)$.

In a study on 97 Brazilian military personnel, NIHL was diagnosed in $38.1 \%$ of the cases. Furthermore, it was observed that the left ear had a higher percentage of hearing loss than the right ear (8).

Pure-tone audiometry is the most commonly used method for NIHL diagnosis, although according to the literature, initial lesions to the auditory system are not immediately detected by pure-tone audiometry and a definitive diagnosis is established only when the damage is already irreversible (9).

Therefore, the use of alternative methods for the detection of hearing loss induced from high sound pressure exposure is of great importance, because the interpretation of the results obtained by pure-tone audiometry can influence the lives of professionals.
Distortion product otoacoustic emissions (DPOAEs) enable a more reliable and objective evaluation of cochlear conditions (10), because this approach is based on obtaining auditory potential in the cochlear region in response to acoustic stimuli, which provides responses with greater reliability.

In a comparative study of the amplitudes of DPOAEs in 12 individuals with normal hearing and 29 patients with sensorineural hearing loss (of mild and moderate degree), it was observed that the higher the hearing loss, the lower the amplitude of DPOAEs (11).

A previous study (12), on 31 patients with NIHL, confirmed a significant correlation between DPOAE and pure-tone audiometry through audiological evaluation. The frequency specificity of this study demonstrated the use of DPOAEs as an additional tool in the diagnosis of NIHL.

In another study (13), researchers collected data on pure-tone audiometry and DPOAEs and calculated the index of DPOAE abnormality to test the hypothesis that the reduction in the DPOAE amplitude is related to the vulnerability to noise exposure. The authors concluded that in individuals with audiometry within the normal range, vulnerability to noise exposure can be verified using DPOAE and that this test may be valuable for assessing and monitoring the hearing health of workers.

In order to evaluate the DPOAE as a method for the diagnosis of initial pathophysiological changes with noise exposure, it was realized an assessment on two groups of workers, one of which is exposed to occupational noise while the other is, all with pure-tone audiometry in the normal range. The estimated risk with the absence of a DPOAE response was 12 times greater for the group exposed to occupational noise at 3, 4, and $6 \mathrm{kHz}$ than for the group not exposed to noise. This finding reinforces the importance of DPOAE as a method for early diagnosis of NIHL because exposure to occupational noise causes changes in DPOAE, even for pure-tone audiometry classified as normal (14).

Another study on DPOAE for workers exposed to noise showed that this population showed prevalence of hearing loss at high frequencies and that this prevalence evolves with the decreasing amplitude of the distortion product and the increase in the frequency spectrum. The authors of that study found an inverse correlation between DPOAE and pure-tone audiometry at all the tested frequencies (15).

From the DPOAE data of subjects with 
sensorineural hearing loss caused by occupational noise exposure, we observed that DPOAE responses were present when the hearing thresholds were within $30 \mathrm{~dB}$ HL. Therefore, the audiometric threshold and the number of frequencies affected are both inversely proportional to the amplitudes of the DPOAE response. Hence, the DPOAE is an efficient method for monitoring clinical hearing loss in conjunction with pure-tone audiometry (16).

A recent study conducted on workers exposed to noise and pesticides has shown that even for individuals who had audiometric thresholds within the normal range, there was significant damage in the DPOAE results as compared to those of the control group (no exposure to unhealthy agents) (17).

Within this line of research, other authors conducted a study on 32 workers exposed to noise and 18 subjects not exposed to noise and concluded that DPOAEs are more sensitive than audiometry in detecting damage in the inner ear and can, therefore, play an important role in tracking and monitoring workers exposed to noise (18).

In a bibliographic review of otoacoustic emissions and differential diagnosis of NIHL, the authors emphasize the importance of this test for the early diagnosis of hearing loss. In addition, the work asserts that DPOAEs are more sensitive than the TEOAEs for the evaluation of hearing loss in workers, because NIHL initially affects the high frequency range while TEOAEs capture frequencies up to $4 \mathrm{kHz}$ (19).

As explained above, the DPOAE is a highly effective tool for the study of NIHL, and the scarcity of studies employing this method for the military police department highlights the need for greater attention from researchers on this topic. The purpose of this study was to assess the correlation between the findings of pure-tone audiometry and the DPOAE results. This study also involved the comparison between the DPOAE amplitudes for normal-hearing individuals and police officers with hearing loss.

\section{METHOD}

The present study evaluated 200 military police personnel in the state of São Paulo, among which 169 (84.5\%) were male and 31 (15.5\%) were females, all aged between 25 and 45 years (mean age of $38.83 \pm$ 5.05) and with an average service time of $16.80 \pm 6.27$ years. Of these, 189 were right-handed and 11, lefthanded. This study was approved by the Ethics on
Research Committee (Protocol No. 2762/2007). The officers voluntarily participated in the audiological evaluation. All the officers were within the proposed age group and showed no pathophysiological changes in the external ear and/or middle ear. Police officers are equipped with personal protective equipment (PPE), according to NR 620 of Decree 3214/78 (1). Relevant to our study is the use of headphones (ear muffs) that have the certificate of approval (CA) by the Labor and Employment Ministry. Before the experiment, we thoroughly studied information on pure-tone audiometry (PTA) and DPOAE testing.

We performed the air and bone conduction test (20) employing pure-tone audiometry, for which we used the GSI 61 Grason-Stadler audiometer within a soundproof booth. The pure-tone audiometry results were classified according to Ordinance No. 19 (21).

The DPOAE was obtained by simultaneously presenting two pure tones, $\mathrm{f} 1$ and $\mathrm{f} 2$. These pure tones, called primary frequencies, have a ratio of 1.22 . In this study, we used the equivalent response to $2 \mathrm{f} 1-\mathrm{f} 2$, and the intensity ratio was $\mathrm{L} 1=65 \mathrm{~dB}$ and $\mathrm{L} 2=55 \mathrm{~dB}$ SPL (sound pressure level). There were considered for analysis frequencies (f2) of 1, 2, 3, 4 and $6 \mathrm{kHz}$. The analysis criteria were based on the results of a study on the clinical application of DPOAEs for individuals with NIHL (22).

The DPOAE evaluation was conducted in a soundproof booth with the device Eclipse EP - 25 Interacoustics. The following analyses were performed from the results obtained:

- Research for possible asymmetries between the right and left ears $(n=200)$ through the Wilcoxon test of signed stations;

- The Spearman correlation analysis for determining the correlation between the results of pure-tone audiometry and DPOAE $(\mathrm{n}=200)$;

- Comparison between DPOAE amplitudes (frequencies (f2) of 3, 4, and $6 \mathrm{kHz}$ ) of two groups: normal listeners (chosen randomly among the subjects, 86 ears) and individuals with hearing loss (these included considered only individuals with bilateral and unilateral hearing loss; a total of 86 ears) through the analysis of variance and the Kruskal-Wallis test.

The research results (pure-tone audiometry and DPOAE) were recorded in decibels (dB) in a logarithmic and not a linear scale. The statistical tests conducted were for nonparametric measures. In all the cases above, the level of significance was 5\% ( $\mathrm{p}<0.05)$ and the confidence interval was constructed with $95 \%$ statistical confidence. 


\section{RESULTS}

The results of pure-tone audiometry indicated an increase in the average threshold from the frequency of $3 \mathrm{kHz}$, and the comparison between the two sides of ears showed a worsening of audiometric thresholds for the left side for most of the frequencies tested, as indicated by the statistical significance at the frequencies of 2 and $3 \mathrm{kHz}$ (Table 1).

Among the 200 police officers evaluated, 142 had audiometric thresholds within the normal range (up to $25 \mathrm{~dB}$ HL); further, in accordance with the provisions of Ordinance No. 19 of the Labor Ministry (23) the results for 58 subjects were suggestive of NIHL, distributed as follows: 28 (48.3\%) bilateral cases and 30 (51.7\%) unilateral cases, 15 (25.85\%) for each ear.

The DPOAE results showed a reduction in the response amplitude from the $3 \mathrm{kHz}$ frequency (f2). Further, from the comparison between the two sides, a worsening of audiometric thresholds was observed for the left side for most of the frequencies tested, indicated by the statistical significance at $3 \mathrm{kHz}$ (table2).

Table I. Analysis of the results of pure-tone audiometry, considering the mean and standard deviation of hearing thresholds ( $\mathrm{dB} \mathrm{HL})$ and a comparison between the right and left ears - Wilcoxon Signed stations test.

\begin{tabular}{cccc}
\hline Frequency $(\mathrm{Hz})$ & RightEar & LeftEar & Pvalue \\
\hline 500 & $7,05 \pm 6,42$ & $6,28 \pm 6,59$ & $0,022 *$ \\
1000 & $7,60 \pm 6,74$ & $7,33 \pm 7,14$ & 0,290 \\
2000 & $6,33 \pm 7,97$ & $7,55 \pm 8,98$ & $0,018 *$ \\
3000 & $13,35 \pm 13,02$ & $15,17 \pm 13,93$ & $0,009 *$ \\
4000 & $16,78 \pm 16,59$ & $18,65 \pm 17,17$ & 0,062 \\
6000 & $18,47 \pm 16,78$ & $20,52 \pm 17,07$ & 0,090 \\
8000 & $17,13 \pm 16,59$ & $16,50 \pm 16,98$ & 0,259 \\
\hline
\end{tabular}

HL - Hearing Level

* Significant difference at $\mathrm{p}<0.05$
The results listed in Tables 3 and 4 demonstrate that statistical significance was observed in most of the frequencies analyzed bilaterally, confirming that the higher the degree of hearing loss, the lower the amplitude of DPOAEs.

For the frequencies (f2) of 3, 4, and $6 \mathrm{kHz}$, we observed significant differences between the DPOAE amplitudes for the normal-hearing and hearing-loss groups (Table 5).

\section{DISCUSSION}

We studied a group of military personnel, which showed peculiar noise exposure characteristics, mainly owing to the use of firearms and the presence of sirens. We believe that the scope of our study is large in Brazil; according to the Brazilian Ministry of Justice Ministry (3), the number of military individuals over various state departments comes close to 600.000 (military police, civilian police, and firefighters).

The results of this study showed peculiar audiological characteristics in the audiometric evaluation;

Table 2. Analysis of the results of distortion productotoacoustic emission ( $\mathrm{f} 2$ ), considering the mean and standard deviation (SPL) and a comparison between the right and left ears Wilcoxon Signed stations test.

\begin{tabular}{cccc}
\hline Frequency $(\mathrm{Hz})$ & RightEar & Leftear & p-value \\
\hline 1000 & $4,92 \pm 6,66$ & $4,71 \pm 7,12$ & 0,649 \\
2000 & $6,92 \pm 7,22$ & $6,20 \pm 7,67$ & 0,070 \\
3000 & $-0,09 \pm 8,62$ & $-1,47 \pm 8,47$ & $0,002 *$ \\
4000 & $-0,58 \pm 11,74$ & $-0,95 \pm 10,72$ & 0,248 \\
6000 & $-10,66 \pm 11,43$ & $-12,0 \pm 10,15$ & 0,068
\end{tabular}

$\mathrm{SPL}-$ sound pressure level

* Significant difference at $p<0.05$

Table 3. Spearman correlation analysis between variables at pure-tone audiometry frequencies of 2,3 , 4, and $6 \mathrm{kHz}$ and DPOAE frequencies (f2) of 2, 3, 4, and $6 \mathrm{kHz}$, for the right ear.

\begin{tabular}{|c|c|c|c|c|c|}
\hline \multirow[t]{2}{*}{ RightEar } & & \multicolumn{3}{|c|}{ DPOAEs $\mathrm{f}$} & \multirow[b]{2}{*}{$6 \mathrm{kHz}$} \\
\hline & & $2 \mathrm{kHz}$ & $3 \mathrm{kHz}$ & $4 \mathrm{kHz}$ & \\
\hline \multirow[t]{4}{*}{ Audiometric Threshold } & $2 \mathrm{kHz}$ & $\mathrm{p}<0,\left.00\right|^{*}$ & $\mathrm{p}<0,\left.00\right|^{*}$ & $\mathrm{p}<0,\left.00\right|^{*}$ & $p=0,0|| *$ \\
\hline & $3 \mathrm{kHz}$ & $\mathrm{p}<0,00 \mid *$ & $\mathrm{p}<0,00 \mid *$ & $\mathrm{p}<0,\left.00\right|^{*}$ & $\mathrm{p}<0,00 \mid *$ \\
\hline & $4 \mathrm{kHz}$ & $p=0,003^{*}$ & $\mathrm{p}<0,00$ |* & $\mathrm{p}<0,\left.00\right|^{*}$ & $p<0,\left.00\right|^{*}$ \\
\hline & $6 \mathrm{kHz}$ & $p=0,103$ & $\mathrm{p}<0,\left.00\right|^{*}$ & $\mathrm{p}<0,\left.00\right|^{*}$ & $\mathrm{p}<0,\left.00\right|^{*}$ \\
\hline
\end{tabular}

* Significance at $p<0,05$ 
Table 4. Spearman correlation analysis between variables at pure-tone audiometry frequencies of 2, 3,4, and $6 \mathrm{kHz}$ and DPOAE frequencies (f2) of 2, 3, 4, and $6 \mathrm{kHz}$, for the left ear.

\begin{tabular}{|c|c|c|c|c|c|}
\hline \multirow[t]{2}{*}{ LeftEar } & \multicolumn{5}{|c|}{ DPOAE $\mathrm{f} 2$} \\
\hline & $2 \mathrm{kHz}$ & $3 \mathrm{kHz}$ & $4 \mathrm{kHz}$ & $6 \mathrm{kHz}$ & \\
\hline AudiometricThreshold & $\begin{array}{l}2 \mathrm{kHz} \\
3 \mathrm{kHz} \\
4 \mathrm{kHz} \\
6 \mathrm{kHz}\end{array}$ & $\begin{array}{l}p=0,00 \text { I* } \\
p<0,00 \text { I* } \\
p=0,0 \mid \text { I * } \\
p=0,876\end{array}$ & $\begin{array}{l}\mathrm{p}<0,00 \text { I* } \\
\mathrm{p}<0,00 \text { I* } \\
\mathrm{p}<0,00 \text { I* } \\
\mathrm{p}<0,00 \text { I* }\end{array}$ & $\begin{array}{l}\mathrm{p}=0,006 \text { * } \\
\mathrm{p}<0,00 \text { I }^{*} \\
\mathrm{p}<0,00 \text { I }^{*} \\
\mathrm{p}<0,00 \text { I }^{*}\end{array}$ & $\begin{array}{l}\mathrm{p}=0,002^{*} \\
\mathrm{p}<0,00 \text { |* } \\
\mathrm{p}<0,00 \text { I }^{*} \\
\mathrm{p}<0,00 \text { I }^{*}\end{array}$ \\
\hline
\end{tabular}

* Significance at $p<0,05$

in $51.7 \%$ of the cases of hearing impairment, the hearing loss was unilateral and there was no prevalence between the right and left sides. The classification of the loss was done using Ordinance No. 19 (21).

However, quantitative analysis, which was considered the means of frequency $(500 \mathrm{~Hz}$ to $8 \mathrm{kHz})$ results of pure tone audiometry were observed an asymmetry, with statistical significance, between the values at $500 \mathrm{~Hz}$, with higher values for the right ear. Higher values were identified for the left ear at 2 and $3 \mathrm{kHz}$. The data presented reinforce the hypothesis that although NIHL has a classic profile as a symmetric, bilateral hearing loss (4), other factors such as the location of the sound source should be considered when analyzing the results $(5,6)$.

It is relevant to note that during a shot camp training with a 12 gauge shotgun (2), we observed that a right-handed police officer's neck tends to lean to the right in search of a better position to target. This movement minimizes the exposure of the right ear and increases the exposure of the left ear to noise. This may be one factor that contributes to a worsening of the high-frequency thresholds for the left ear.

The DPOAE findings also confirmed the asymmetry between the sides; there was a decrease in the amplitudes for the left ear at $3 \mathrm{kHz}$ in relation to the other side, as confirmed by the statistical significance.

The prevalence of unilateral hearing loss in military population has been reported previously ( 8 , $13)$, because this population is exposed to varying levels of noise and because the amount of noise to which each ear is exposed varies with the use of firearms and the type of service provided $(6,16)$.

From the analysis of the DPOAE responses obtained, we determined that the high frequencies (3$8 \mathrm{kHz}$ ) showed the lowest amplitude. A greater
Table 5. Analysis of DPOAE amplitudes, considering average and standard deviation (SPL), for normal-hearing and hearingloss groups ( $\mathrm{n}=86$ ears for each group).

\begin{tabular}{lccc}
\hline DPOAE & Normal Hearing & Hearing Loss & $p$-value \\
\hline $3 \mathrm{kHz}$ & $3,31 \pm 5,68$ & $-8,48 \pm 9,06$ & $\mathrm{p}<0,00$ I $^{*}$ \\
$4 \mathrm{kHz}$ & $4,37 \pm 6,68$ & $-12,23 \pm 12,62$ & $\mathrm{p}<0,00$ * $^{*}$ \\
$6 \mathrm{kHz}$ & $-6,39 \pm 8,51$ & $-20,68 \pm 8,28$ & $\mathrm{p}<0,00$ । $^{*}$ \\
\hline
\end{tabular}

SPL - sound pressure level

* Significant difference at $\mathrm{p}<0.05$

susceptibility to high frequencies was also observed by other researchers $(13,15)$. Another relevant study reported that noise exposure increases the absence of DPOAEs in these frequencies (14).

The correlation between the mean frequencies for pure tone audiometry and mean amplitudes of the frequencies for otoacoustic emissions distributed on Tables 3 and 4 showed strong statistical significance between these variables. Therefore, we determined that the higher the threshold observed in pure-tone audiometry, the lower the amplitude of the DPOAEs.

In the present study a significant difference was also observed among the DPOAE amplitudes of individuals with normal hearing and of those with hearing loss, thus confirming the lowering of the response amplitude for the hearing-loss group. This finding is in agreement with the comparative literature $(11,15)$.

It is also important to consider that other researchers have reported otoacoustic emissions show greater sensitivity in comparison with pure-tone audiometry $(17,18)$ and that low amplitudes of DPOAEs are reported to pose a higher risk of hearing loss (10). 


\section{CONCLUSION}

Considering the exposed, we found a significant correlation between the results of pure-tone audiometry and DPOAEs. Our results demonstrate that DPOAEs can be a complementary tool for the detection and control of NIHL in military police.

\section{BibliOgRAPHICAL ReFERENCES}

1. Brasil. Ministério do Trabalho. Portaria no 3214, 08 de julho de1978; NR 15. Atividades e operações insalubres. DOU, 06 de julho de 1978.

2. Guida HL, Kinoshita SK. Quantificação dos níveis de ruído no estande de tiros da polícia militar/Marília -SP. Em: Anais do $23^{\circ}$ Encontro Internacional de Audiologia; 2008, 1215 março; Itajaí, Brasil. Itajaí: Academia Brasileira de Audiologia, 2008. p.1440.

3. Brasil. Ministério da Justiça do Brasil. Segurança Pública, estatística. [citado em 2011 ago 01]. Disponível em: http://portal.mj.gov.br/data/Pages/ M J C F 2 B A E 97 I T CEEFBA784458E99DCADBC672C3096PTBRIE.htm

4. Comitê Nacional de Ruído e Conservação Auditiva. Perda auditiva induzida pelo ruído relacionado ao trabalho. Acta Awho. 1994, 13(3):126-7.

5. Teles RM, Medeiros MPH. Perfil audiométrico de trabalhadores do distrito industrial de Maracanaú-CE. Rev Soc Bras Fonoaudiol. 2007, 12(3):233-9.

6. Harger MRHC, Barbosa-Branco A. Efeitos auditivos decorrentes da exposição ocupacional ao ruído em trabalhadores de marmoraria do Distrito Federal. Rev Ass Med Bras. 2004, 50(4):396-99.

7. Flamme G, Wong A, Liebe K, Lynd J. Estimates of auditory risk from outdoor impulse noise II: civilian firearms. Noise Health. 2009, 11(45):231-42.

8. Silva AP, Costa EA, Rodrigues SMM, Souza HLR, Massafera VG. Avaliação do perfil auditivo de militares de um quartel do Exército Brasileiro. Rev Bras Otorrinolaringol. 2004, 70(3): 344-50.

9. Glorig A. Noise: past, present and future. Ear Hear. 1980, $1: 4-18$.

10. Marshall L, Miller JAL, Heller LM, Wolgemuth KS, Hughes LM, Smith SD, Kopke RD. Detecting incipient inner-ear damage from impulse noise with otoacoustic emissions. J Acoust Soc Am. 2009, 125(2):995-1013.

11. Kós MI, Almeida K, Frota S, Hoshino ACH. Emissões otoacústicas produto de distorção em normo ouvintes e em perdas auditivas neurossensoriais leve e moderada com os protocolos 65/55 dBNPS e 70/70 dBNPS. Rev Cefac. 2009, 11(3):465-72.

12. Gattaz G, Wazen SRG. O registro das emissões otoacústicas evocadas - produto de distorção em pacientes com perda auditiva induzida pelo ruído. Rev Bras Otorrinolaringol. 2001, 67(2):213-18.

13. Job A, Raynal M, Kossowski M, Studler M, Ghernaouti C, Baffioni-Venturi A, Roux A, Darolles C, Guelorget A. Otoacoustic detection of risk of early hearing loss in ears with normal audiograms: a 3 year follow-up study. Hear Ear. 2009, 251(1):10-16.

14. Marques FP, Costa EA. Exposição ao ruído ocupacional: alteração no exame de emissões otoacústicas. Rev Bras Otorrinolaringol. 2006, 72(3):362-6.

15. Fukuda C, Munhoz MSL, Toledo FB, El Hassan S. Emissões otoacústicas por produto de distorção em trabalhadores expostos a ruído. Acta Awho. 1998, 17(4):176-85.

16. Konopka W, Olszewski J, Pietkiewicz P, Mielczarek M. Distortion product otoacoustic emissions before and after one year exposure to impulse noise. Otolaryngol Pol. 2006, 60(2):243-47.

17. Guida HL, Morini RG, Cardoso ACV. Avaliação audiológica e de emissões otoacústicas em indivíduos expostos a ruído e praguicidas. Arq Int Otorrinolaringol. 2009, 13(3):264-9.

18. Atchariyasathian V, ChayarphamS, Saekhow S. Evaluation of noise-induced hearing loss with audiometer and distortion product otoacustic emissions. J Med Assoc Thai. 2008, 91(7): 1066-71.

19. Coelho MSB, FerrazJRS, Almeida EOC, Almeida Filho, N. As emissões otoacústicas no diagnóstico diferencial das perdas auditivas induzidas por ruído. Rev Cefac. 2010, 12(6): 1050-58.

20. Santos TMM, Russo ICP. A prática da audiologia clínica. 5a ed. São Paulo: Cortez Editora, 2005.

21. Brasil. Ministério do Trabalho. Portaria no 19 GM/SSSTb, de 9 de abril de 1998. Estabelece diretrizes e parâmetros mínimos para avaliação e acompanhamento da audição em 
trabalhadores expostos a níveis de pressão sonora elevados. DOU, 22 de abril de 1998.

22. Fiorini AC, Parrado-Moran MES. Emissões otoacústicas produto de distorção: estudo de diferentes relações de níveis sonoros no teste em indivíduos com e sem perdas auditivas. Dist Comun. 2005, 17(3):385-96. 